\title{
Mapping Indigenous Settlement Topography in the Caribbean Using Drones
}

\author{
Till F. Sonnemann ${ }^{1, *}$, Jorge Ulloa Hung ${ }^{2}$ and Corinne L. Hofman ${ }^{1}$ \\ 1 Faculty of Archaeology, Leiden University, Leiden 2333 CC, The Netherlands; c.l.hofman@arch.leidenuniv.nl \\ 2 Área de Ciencias Sociales, Instituto Tecnológico de Santo Domingo (INTEC), Santo Domingo 10602, \\ Dominican Republic; ulloahungprofessor@gmail.com \\ * Correspondence: tillsonnemann@hotmail.com; Tel.: +31-71-527-1966
}

Academic Editors: Kenneth L. Kvamme, Henrique Lorenzo, Richard Gloaguen and Prasad S. Thenkabail Received: 15 July 2016; Accepted: 19 September 2016; Published: 23 September 2016

\begin{abstract}
The archaeology of Amerindian settlements in the Caribbean has mostly been identified through scatters of artefacts; predominantly conglomerations of shells, ceramics and lithics. While archaeological material may not always be visible on the surface, particular settlement patterns may be identifiable by a topography created through cultural action: earthen mounds interchanging with mostly circular flattened areas. In northern Hispaniola, recent foot surveys have identified more than 200 pre-colonial sites of which several have been mapped in high resolution. In addition, three settlements with topographical characteristics have been extensively excavated, confirming that the mounds and flattened areas may have had a cultural connotation in this region. Without the availability of high resolution LiDAR (Light Detection and Ranging) data, a photogrammetric approach using UAS (unmanned aircraft system, commonly known as drones) can fill the knowledge gap on a local scale, providing fast and reliable data collection and precise results. After photogrammetric processing, digital clearance of vegetation, and extraction of the georeferenced DEM (digital elevation model) and orthophoto, filters and enhancements provide an opportunity to visualize the results in GIS. The outcome provides an overview of site size, and distribution of mounds and flattened areas. Measurement of the topographic changes in a variety of past settlements defines likely zones of habitat, and provides clues on the actual dimensions and density of living space. Understanding the relation of the mounds and adjacent flat areas within their environment allows a discussion on how, and for what purpose, the settlement was founded at a particular location, and provides clues about its spatial organization.
\end{abstract}

Keywords: Caribbean archaeology; settlement studies; landscape archaeology; topography mapping; photogrammetry; drones

\section{Background and Rationale}

Of the hundreds of thousands of indigenous people that populated the Greater Antilles at the time of colonial encounters, only few survived the decades following the arrival of Columbus in 1492 due to diseases, mistreatment, enslavement and famine [1] (pp. 90-101). Because of the dramatic decline of the local population on the island of Hispaniola, and few records about their settlements in contemporary Spanish historical sources [1,2], knowledge about life and organization of these communities has to be gathered by other means. Archaeological research has increasingly taken a leading role in understanding society, life and death of the island's precolonial population [3,4]. Evidence of Hispaniola's once dense population pattern is encountered in the material culture remains of the numerous settlements that dotted the island, many of which have been identified in archaeological surveys [5-10], [11] (pp. 239-275), [12]. The size of the currently known pre-Hispanic archaeological settlement sites ranges from small villages of less than a hectare, to larger settlements, 
such as the exceptional En Bas Saline in Haiti, that extends over two square kilometers [13,14] (p. 73). The settlements' dimension also depends on their location and accessibility [10,15,16]. Coastal production sites were situated near the mangrove forests, while it appears that large scale settlements were situated in flatter regions in the hinterland, and connected via smaller 'lookouts' on hill tops in the Cordillera Septentrional, which separates the fertile Cibao valley with the river Yaque from the sea [10] (pp. 359-421). Many settlements are located in regions that are only reachable by foot using a machete, as they are on steep slopes in forested areas, making an investigation with heavy equipment difficult. While the main focus of surveys has been on the interpretation of the material finds, extensive foot surveys discovered that the terrain of a number of settlements had been modified intensely by the people living there, marking out small mounds of which some were later excavated [4]. Up until today, the mounds had been visualized as dots on a map, since the full mapping of these sites by total station or D-GPS (differential global positioning system) turned out to be extremely difficult. With increasing knowledge of the sites, it became clear that in between the mounds are leveled, often circular areas, 10 to $15 \mathrm{~m}$ in diameter, that served as the base for the houses. Due to their very subtle height differences of a few decimeters in difficult, overgrown terrain, the features are very difficult to see from the ground or in coarse DEMs (digital elevation models) and were extremely difficult to visualize prior to the advent of drone-generated DEM technology.

The rapid development in drone technologies in combination with photogrammetric techniques, can exceed the resolution of LiDAR (Light Detection and Ranging) in non-obstructed areas. This allowed the production of high resolution digital elevation models of these Amerindian settlements for interpretation and comparison. Because of the technique's applicability in the field and affordability, it is likely to become a standard tool for archaeologists. The mapping of these minor anthropogenic topographic anomalies of the settlements, combined with the photographic data, can add new insights when visualized in GIS (geographic information system). In the Caribbean, the technique assists in mapping the layout, size and structure of places of habitation; gathering trade and production, permitting for first time the capability of visualizing these subtle Caribbean settlements.

\section{Objectives}

Archaeological research on indigenous settlement styles in the Spanish dominated Caribbean has long been characterized by archaeological excavations of small dimensions [7,8,17-23], which has contributed to a limited vision of the ways in which Native American groups changed the landscape. From that approach, the landscape has been essentially conceived primarily as a set of economic resources, whose exploitation directly conditioned social development of those communities.

The identification of Amerindian archaeological evidence in the Caribbean is dominated by surface material which serves as diagnostics: assemblages of punctuated sea shells, as well as ceramic sherds and lithics, such as stone tool fragments. The preferred method to georeference and register these sites in the north of Hispaniola has been the opportunistic, non-systematic field survey, depending on local knowledge and oral history, and involves community members as guides. Over several years the approximate size of a number of sites has been recorded and a small number of samples collected [15]. This approach has provided the opportunity to study location, distribution of material, and the potential interrelations between sites [7,10,15,24,25]. Many of the settlements recorded are positioned on mountain tops and plateaus of the Cordillera Septentrional, at altitudes between 50 and $700 \mathrm{~m}$ above sea level. Distance to the ocean varies from less than 0.5 up to $40 \mathrm{~km}$ (Figure 1). Another influencing factor was proximity to a water source, as many sites are situated near valleys, alluvial basins, and terraces or near the most important rivers of the region [10], e.g., the Amina, Mao, Yaque, Canas, Bahabonico, and Unijica all being indigenous place names. High inter-visibility existed between settlements. Based on extensive archaeological field work conducted earlier (not GIS analysis), it was estimated that, from most sites, it was possible to see a minimum of three other sites, and either the ocean or the Cibao Valley were in view [10]. An example of visualizing this in GIS has been shown 
for the site of El Manantial [25]. This constituted a strategic priority for management and control of space; linked to a system of settlements, where partnerships and interactions connected different areas within the region [10].

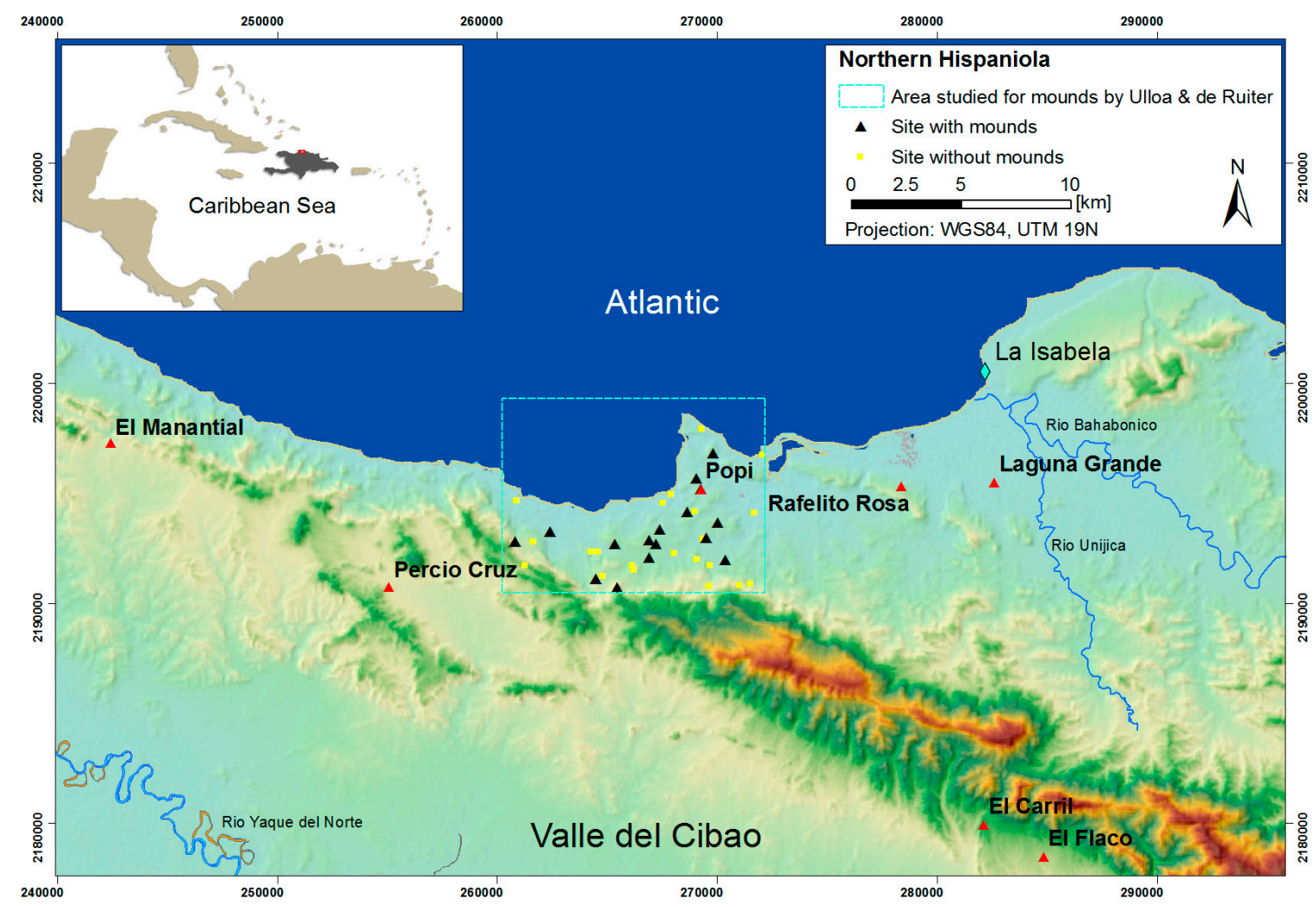

Figure 1. Regional overview of the northern Dominican Republic with an earlier study area to determine sites with mounds (black triangles) and without any (yellow triangles). Sites featured in the article are marked by red triangles.

So far, only a small number of sites have been widely and systematically excavated in order to understand the diversity of forms of an indigenous settlement, and most were sites of larger dimensions, such as Atajadizo [26], El Cabo [3,27,28] located in the easternmost part of the island; and the sites of Playa Grande [29], El Flaco [4], and the Haitian En Bas Saline [30], located in the northern part. In some of these studies, as well as recent research, one of the main focuses of attention were the mounds ([10] p. 143.), [25,31,32] with the intention to better understand their distribution and functionality, as well as to document the existence of dwellings, or other structures associated with them [4]. Following the field walking, a small number of test pit excavations and coring were performed into mounds to verify an anthropogenic origin [10] in this karstic landscape where small changes in the topography are common. However, none of the studies published so far included a comprehensive and comparative topographic landscape survey to understand the space in between the mounds. In this regard, the few published examples on geophysical prospection surveys of Amerindian heritage in the Caribbean show only limited success [33-35], and excavations have been the main method to approach the subject in depth. The newly introduced drone photogrammetry also relied on the information from earlier field surveys and site visits, to identify sample sites that had the right attributes for a successful survey. The Amerindian dwellings were single story, circular structures made from wood and thatch that existed in different sizes, from seven to ten meters in diameter [3] depending on their function. They are represented by small depressions in the ground, where the slope was once flattened for the house base (Figure 2). Today, archaeological excavations only reveal the remaining postholes. Excavations of up to one meter deep and five to ten meters wide showed that 
the layered artificial mounds had multiple functions, i.e., from garbage deposits, to kitchen gardens, cooking areas and burial grounds [4].

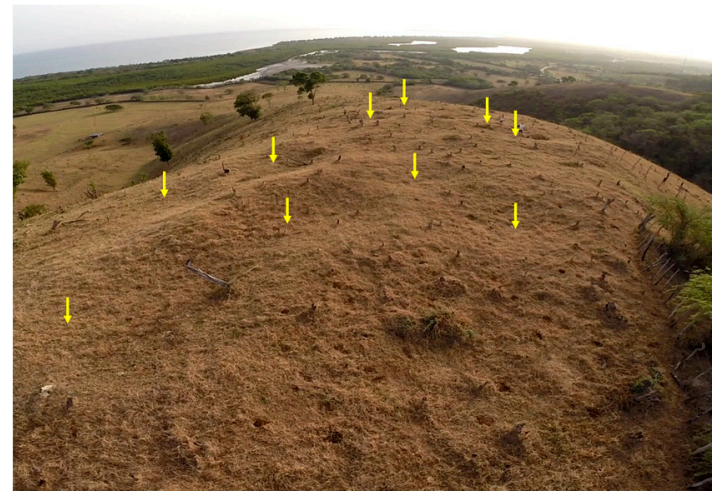

(a)

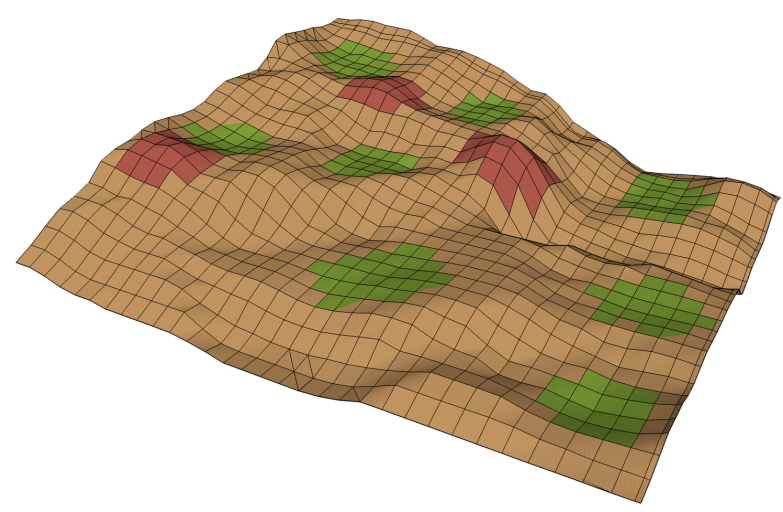

(b)

Figure 2. (a) A drone image showing the human impact on the topography of the Rafelito Rosa site with the flattened areas shaded by the morning sun, are marked by yellow arrows; (b) a 3D sketch highlights the type of topography that the survey focused on: green squares pointing out the concave form of the flattened areas, bounded by the mounds colored in dark red.

\section{Methods}

Unlike places of particular interest, such as the volcano of Montserrat [36] or promising natural resources, few regions in the Caribbean have been flown with high resolution LiDAR, and the Dominican Republic is not one of these countries. Drone photogrammetry can fill the void for mapping surveys in a local perspective. The tradition to utilize aerial imagery in archaeology is nearly as old as the first flight trials, and satellite and aerial platforms with active and passive sensors that reach into frequencies outside the visible electromagnetic spectrum have also been embraced in archaeology (e.g., hyperspectral [37], or SAR (synthetic aperture radar) [38,39]). While here, using only the visible spectrum, the particular advantages of drones in archaeology are their simple operability [40]: flights can be set up anytime and anywhere, can be frequently repeated, and image resolution is only dependent on flight height or distance to the target [41]. The main disadvantage is the limited flight time and area coverage. Poor weather such as rain or high winds, high and thick vegetation restrict recording possibilities, and flight regulations have increased, which vary by country. The method was tested initially at El Manantial, a large open site in the Dominican province of Montecristi, to compare the interpretation from field survey and satellite imagery with the topographic outcome from the drone flights [25].

Another aspect has been the improved applicability of photogrammetric software, facilitating the processing workflow in the construction of DEMs [41], which has resulted in numerous applications in archaeological and heritage studies [42-49]. While photography and associated photogrammetry is limited by vegetation [43], the pivotal gimbal of the applied camera drone allows the collection of vertical, as well as oblique aerial photos in one flight, providing coverage below the canopy of individual trees. Shrub or high ground vegetation, however, has proven impenetrable, resulting in reduced data capture, at times leaving voids in the DEM; only limited filtering was done in the resulting point cloud to solve this problem.

The surveys were performed using a DJI Phantom II quadcopter with a GoPro 3+ connected by a gimbal H3-2D, and later by a H3-3D; see Table 1 for specifications. 
Table 1. Technical aspects, acquisition and processing parameters applied in the photogrammetric survey.

\begin{tabular}{ll}
\hline UAS & Attributes and Parameters \\
\hline Platform & DJI Phantom 2 + Gimbal H3-3D \\
Camera & GoPro Hero 3+, 12MP, Fisheye lens \\
Focal Length & 2.77 \\
Camera angle & $\sim 45 \mathrm{deg}$ \\
Data Collection & 1 photo $(4000 \times 3000$ pixel) per second \\
Flight height above surface & $30-50 \mathrm{~m}$ \\
Processing Software & Agisoft Photoscan Professional 64 Bit V1.2.5 \\
Camera Accuracy & $10 \mathrm{~m}$ \\
Marker Accuracy & $0.005 \mathrm{~m}$ \\
Visualization Software & ArcGIS 10.2.2 (ArcMap, ArcScene) \\
\hline
\end{tabular}

Using a non-programmable drone, flights had to be done in a non-systematic pattern, with continuous view of the quadcopter, generally setting the gimbal to a 45 degree angle. The camera was set to its highest resolution of $12 \mathrm{MB}$, taking one photo every second, resulting in the collection of several hundred photos per site (Table 2). As ground control points, large white reference crosses were laid out as markers at the site and measured by total station and handheld GPS to extract and geo-reference the photogrammetric model. Depending on site size and tree coverage, between four and eight markers could be identified in the photogrammetric models. Most images are displayed in a local coordinate system. The accuracy of the handheld GPS was insufficient to precisely georeference the models since the elevation changes needed to be recorded in high accuracy. Another reason is to prevent looting of these unprotected sites with sensitive archaeological information. The approximate location of all surveyed sites can be found in Table 2 .

Table 2. Location and data collection information of all flown sites discussed in the text (Coordinate System: UTM WGS84, 19N).

\begin{tabular}{lccccc}
\hline \multicolumn{1}{c}{ Site Name } & Easting $(\mathbf{m})$ & Northing $(\mathbf{m})$ & No. of Photos & $\begin{array}{c}\text { Ground Control } \\
\text { Points (GCP) }\end{array}$ & $\begin{array}{c}\text { Projection Err. } \\
(\mathbf{m})\end{array}$ \\
\hline El Flaco (August 2014) & 284,799 & $2,178,423$ & 997 & 5 & 0.66 \\
El Flaco (October 2014) & & & 291 & 4 & 0.08 \\
El Flaco (July 2015) & & 320 & 4 & 0.07 \\
El Manantial & 242,329 & $2,197,200$ & 380 & 4 & 0.22 \\
El Carril & 282,175 & $2,180,074$ & 861 & 8 & 0.17 \\
Rafelito Rosa & 278,372 & $2,195,310$ & 301 & 4 & 0.06 \\
Popi & 269,477 & $2,194,266$ & 255 & 5 & 0.20 \\
Percio Cruz & 254,995 & $2,190,584$ & 308 & 5 & 0.07 \\
Negrito & 279,470 & $2,195,037$ & 350 & 4 & 0.06 \\
Laguna Grande & 282,502 & $2,195,516$ & 356 & 5 & 0.07 \\
Chacuey & 230,707 & $2,158,124$ & 206 & 5 & 0.03 \\
\hline
\end{tabular}

The collected images were processed in Agisoft Photoscan following standard photogrammetric procedures to create a high resolution DEM and orthophoto for each site. The structure-from-motion algorithm performed well, considering the use of a not manually calibrated and strongly distorting 'fisheye' lens, and utilizing the full photo for processing. The software however recognizes the camera lens correctly, adjusting the distortion and minimizing the error. Earlier trials for mapping structures had been successful applying the automatic calibration of the camera [50]. The high density point cloud was manually cleared of pixels from trees and bushes, leaving only topographic information for the mesh creation. Marker crosses were identified in overlapping pictures and given the associated xyz-reference. As in most cases, they were recorded by total station, this means heights and locations were measured in a site specific reference system, while GPS points were taken by handheld GPS for the approximate site location. The resulting 3D models and orthophotos were exported and uploaded into ArcGIS for visualization and analysis. ArcScene was also particularly helpful to rotate the DEMs, to better understand and map the topography in a 3D view. Other algorithms such as 'sky view factor' [51], 'slope gradient', and 'openness', were tried through software commonly used for LiDAR 
data (such as the 'Relief Visualization Toolbox'), which did not improve the visualization. To extract the subtle differences of mounds and flattened areas to the natural environment, a combination of three representations of the topography were created and overlaid in ArcGIS: a color DEM (50\% visibility), slope $(50 \%$ visibility, from less slope $=$ dark, to strong slope $=$ light $)$, over a hill shade model. This combination allowed the picking out of the circular dark areas of lesser slope, most likely showing the flattened areas of former houses, while the mounds are distinguished by their convex form and are highlighted by the DEM color representation. The color scheme of the DEM was set to range from the lowest to the highest point of where the terrain modification was identifiable within each settlement, to distinguish the slight height differences between flattened areas and mounds in the highest resolution possible, disregarding the height difference of the full DEM range. The height difference lies between a few decimeters and several meters on hill side settlements. Looking through different visualizations of models and orthophotos in 2D and 3D and external drone material, both types, mounds and flattened areas, were marked in GIS as polygons and their dimension calculated for statistical analysis.

\section{Discussion}

The site of El Flaco is located on the southern slope of the Cordillera Septentrional, overlooking the Valle del Cibao along the Ruta de Colon; the route that Columbus used in 1494 to conduct initial colonization campaigns, and conquer the island [4,52-55]. While large trees remain standing, large areas of the medium size settlement were cleared of brush for large scale excavations. The site's topography was recorded by drone three times over the period of one year $[48,56]$. Combined with surface survey and excavations the results showed a pattern of mounds and platforms [4], providing hints on settlement pattern and spatial layout of Amerindian settlements. The natural slope had been artificially transformed into a landscape of interchanging mounds and flattened areas. The excavations revealed that at this location, however, not all mounds were anthropogenic: some of them were remainders of the topography of the karstic rock base. Between the mounds, the flat areas or platforms revealed large numbers of circularly arranged postholes, remains of large circular structures for habitation, approximately 7 to $10 \mathrm{~m}$ in diameter, and smaller circles of cooking huts and auxiliary buildings [4] (Figure 3).

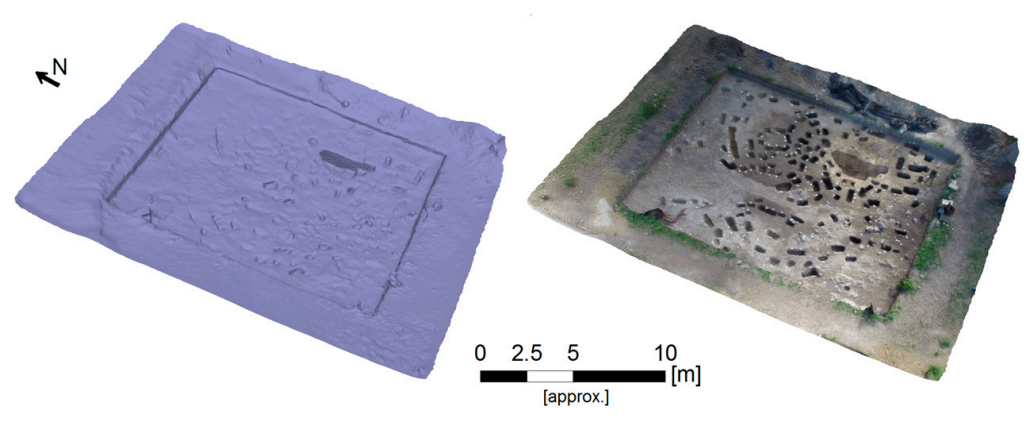

(a)

(b)

Figure 3. Photogrammetric detail, as (a) mesh; and (b) textured model, of excavation area U34 (see location in Figure 4c) at El Flaco, displaying the transected postholes that form circular shapes.

When disregarding the excavated areas and spoil piles, the photogrammetric results mark out the complex topography of the site (Figure 4). As a trial survey, ground penetrating radar profiles were carried out at El Flaco, intending to visualize the mounds in a GPR transect. Using a Mala 250 Mhz cart system the limited quality of the radargrams, however, showed neither bedrock depth—at some locations only about $50 \mathrm{~cm}$ below the surface-nor the delimitations of the anthropogenic mounds. In the investigated region, the method was therefore deemed unsuitable to clearly define archaeologically relevant Amerindian evidence.

Based on the photogrammetric results from El Manantial and El Flaco, six late pre-colonial archaeological sites were selected based on three factors: their indisputably transformed landscape, 
limited vegetation, and a relatively small impact by modern development or agriculture. In that sense, these sites differ from the site of El Manantial, where modern deep ploughing had affected the topography immensely, leaving only traces of the mounds and revealing no flattened areas for potential house constructions [25]. El Carril is located in Valverde Province, while Laguna Grande, Popi, Negrito and Rafelito Rosa are in Puerto Plata, and Percio Cruz in Montecristi, see Figure 1. These six sites represent a variety of location types, including flat terrain, hilltops, flanks and ridges. The sites of Laguna Grande and El Carril can be considered large habitation sites, while El Flaco and Percio Cruz are midsize. Rafelito Rosa, Negrito and Popi are smaller; their extent is delimited by the environmental setting in their location, e.g., situated on steep inclines (Negrito) or hilltops (Rafelito Rosa). Small scale excavations had been conducted at most of these sites to obtain an insight into the chronology and stylistic affiliation $[7,10,11]$.

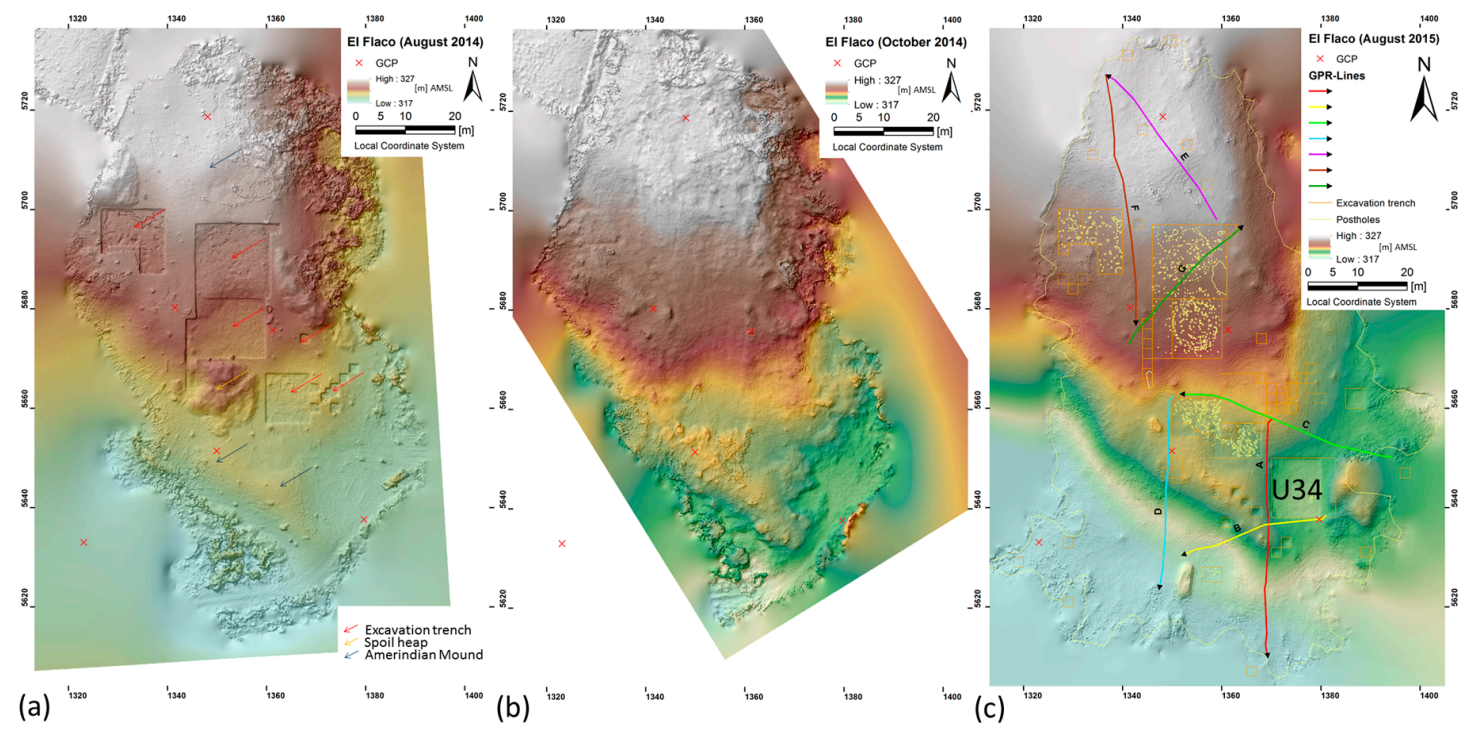

Figure 4. Changes of the topography over time, visualized as a digital elevation model (DEM) overlaying a hill shade model, created from drone imagery at the Amerindian settlement site of El Flaco from (a) August and (b) October 2014, as well as (c) August 2015, with the transects of the GPR (ground penetrating radar) survey.

The surveys counted considerably less mounds (varying between 8 and 42) than flattened areas (between 17 and 78) at either site (see Table 3). This discrepancy, however, may be a result of the verification method: the often circular flattened areas appear relatively clear in the photogrammetric results, while the presence, sfhape, and size of the mounds are not only linked to cultural processes but often include the characteristics of the topography. The exact number of anthropogenic mounds could only be verified by investigating the stratigraphy through excavations or coring.

Table 3. Comparison of sites. So far, for El Flaco, comparable parameters have not been available due to the thick vegetation surrounding the site. Deep ploughing has severely altered the topography at El Manantial.

\begin{tabular}{cccccccc}
\hline Site Name & $\begin{array}{c}\text { Altitude } \\
(\mathbf{m})\end{array}$ & $\begin{array}{c}\text { Estim. Settlem. } \\
\text { Size } \mathbf{( m}^{\mathbf{2}} \mathbf{)}\end{array}$ & $\begin{array}{c}\text { Distance from } \\
\text { Sea } \mathbf{( k m )}\end{array}$ & Terrain & $\begin{array}{c}\text { No. of } \\
\text { Flattened Areas }\end{array}$ & $\begin{array}{c}\text { No. of } \\
\text { Mounds }\end{array}$ & $\begin{array}{c}\text { Potential } \\
\text { Central Plaza }\end{array}$ \\
\hline El Flaco & 300 & $/$ & 19.3 & Flank & Yes & Yes & No \\
El Manantial & 170 & 10,179 & 3,8 & flat & destroyed & 32 & unclear \\
El Carril & 300 & 44,582 & 17.5 & ridge & 78 & 42 & Yes \\
Laguna Gr. & 20 & 14,511 & 3.6 & flat & 30 & 14 & Yes \\
Percio Cruz & 200 & 9467 & 5.8 & ridge & 23 & Yes \\
Rafelito Rosa & 70 & 4519 & 1.2 & top & 28 & 17 & No \\
Negrito & 40 & 5478 & 2.0 & ridge & top & 20 & No \\
Popi & 70 & 8198 & 1.6 & & & No \\
\hline
\end{tabular}


The settlements of Negrito, Popi and Rafelito Rosa show a number of similarities. They are situated relatively close to the sea, are at comparable heights, and face the Atlantic coast in viewing distance, providing optimal visibility. Only the uppermost part of these hill sites show clear transformation, indicating that the combination of good visibility and a gentle slope could have influenced the set up at this location. This area was transformed to human needs by using the existing topography and the limited available space. While located at different spots and varying environments, a similar number of flattened areas was counted, indicating small villages. The arrangement of the flattened areas appears intentional, using, but also alternating, the local topography, creating a dispersed rather than centralized village, a pattern mentioned also in historic accounts [57]. At Negrito the flattened areas are lined up along the down sloping ridge, each situated a bit lower than the previous one, using the narrow space completely. At Popi the broader space and flatter terrain allowed two parallel rows of flattened areas next to each other. Rafelito Rosa (see Figure 5) is located 70 m.a.s.l. (meters above sea level), on top of a hill with a steep slope overlooking the Atlantic Ocean. The area was recently freed of tree cover, leaving only tree stumps and light shrub, and revealing a generally undisturbed surface. The flattened areas are arranged as terraces from the ridge of the hill downwards, which would have provided each single story hut a view towards the sea. All flattened areas appear to have been dug into the hill, each protected by an earthen ring wall uphill. The slope model, enhanced by a hill shade overlay, shows that adjacent platforms partly intersect, or are in very close proximity to each other. If all flattened areas had been occupied simultaneously, the buildings would have been very close to each other, allowing little communal space in between but possibly providing protection from strong winds.
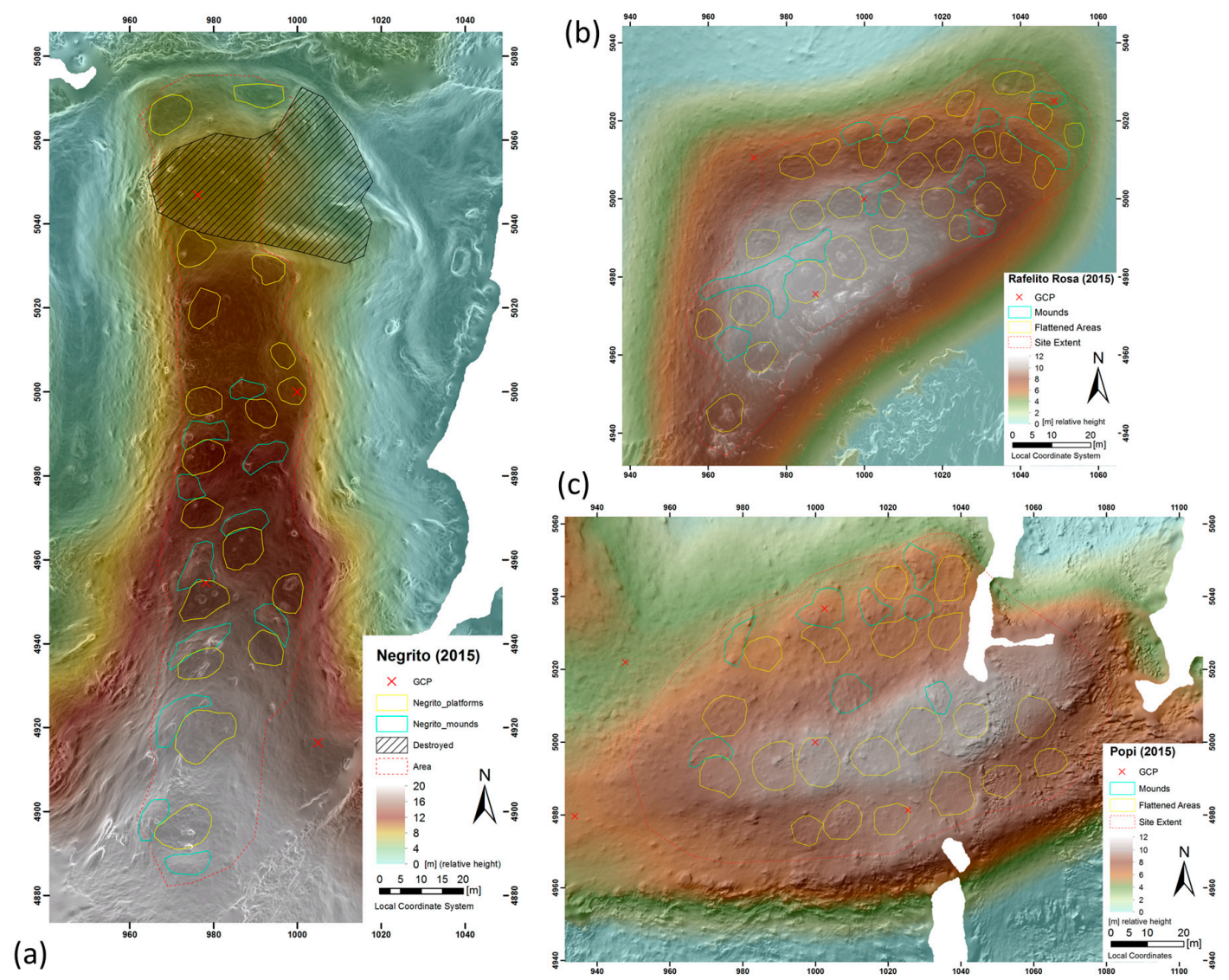

Figure 5. The three sea-facing smaller settlement sites. Particularly at (a) Negrito and (b) Rafelito Rosa are the flattened areas highlighted by the DEM-hillshade combination, while at (c) Popi the stronger vegetation complicated the extraction for features. Compared to the flattened areas (yellow), the mounds (mint) are more difficult to distinguish. 
The more leveled terrain at Percio Cruz and El Carril, situated on broad hill tops, or Laguna Grande, in the coastal plain, provided space to spread out further. Although very different in size, all three settlements seem to have a large flattened area within the spatial layout. Percio Cruz (Figure 6) is located in a valley south of the main range of the Cordillera Septentrional, on a small hill that is dwarfed by the mountains in their surroundings. Dotted with small trees, the area is used for grazing. The strategic location allows a visual control of most of the valley, its flat ridge is delimited at three sides by a steeper slope, while the site opens up to the west into a broader space of the same elevation that remained unmodified. The flattened areas are positioned on the hill top, and on its southern flanks, some of which intersect with each other, complicating the individual count. Most flat or likely house areas are at the same height level, either dug into the soil or delimited by earthworks, while the slope further downhill has not been visibly altered.

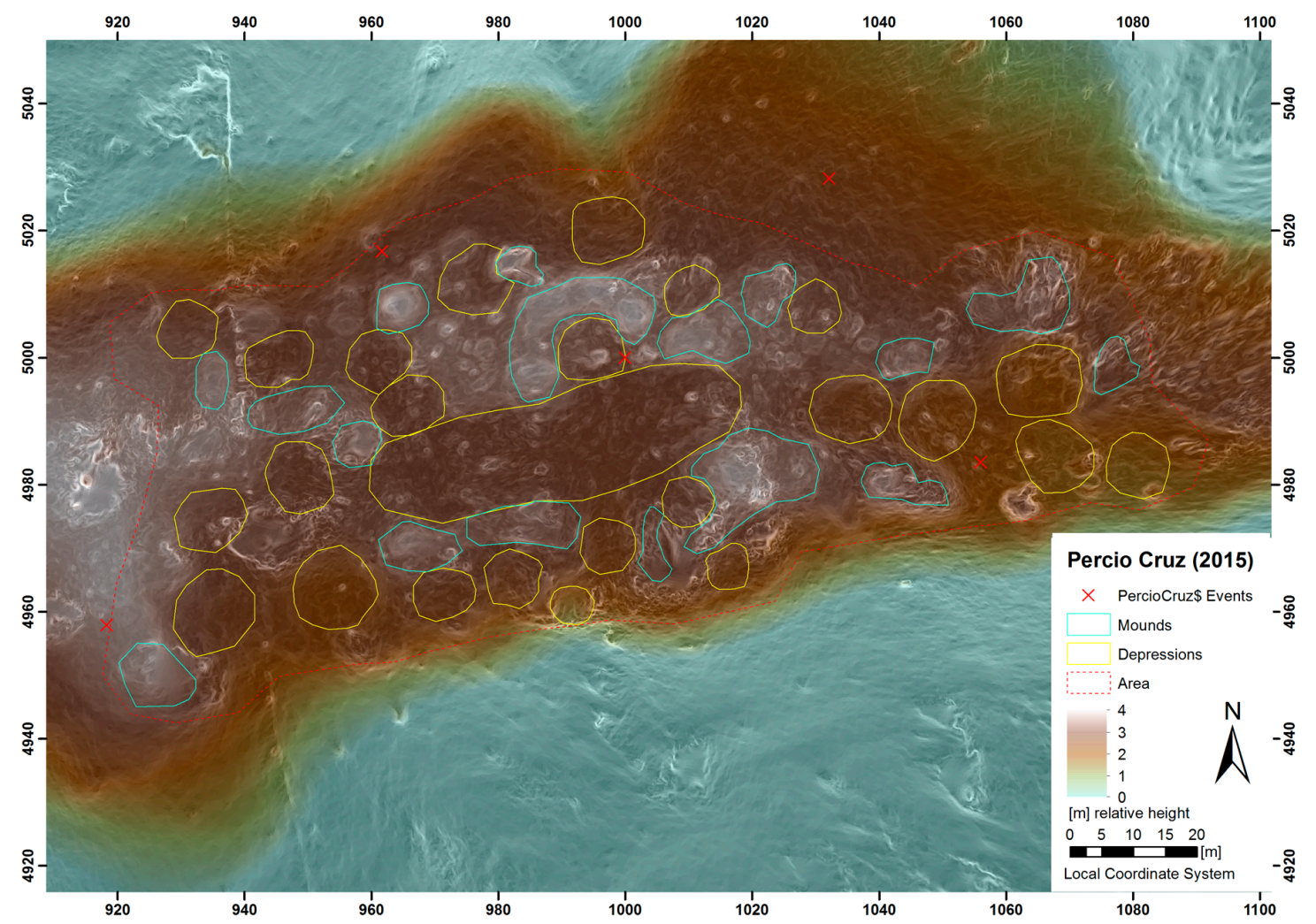

Figure 6. DEM overlaying a hill shade model, and the interpretation of mounds and flattened areas at the settlement site of Percio Cruz.

Located in a mostly flat floodplain, the location of Laguna Grande (Figure 7) is not limited by any natural barriers. A low lying hill provides only minimal visibility. All flattened areas were detected alongside the western part of the hill and dug into the elevated area, which is delimited to the east by a straight cut off. Whether this was the limit of a communal space, a type of plaza, or a modern alteration is not readily determinable. The latter was deemed a possibility due to the very recent construction of a water catchment on the western side.

The site of El Carril (Figure 8) dominates the southern exit of a narrow gorge transecting the Cordillera Septentrional. Evidence of the settlement is found over a stretch of over five hundred meters in length, and the particular location may have had an influence on its size. The southern part is a broad, flat ridge, while the northern part, separated by a modern road, rises towards the North. The whole settlement is delimited on its sides by a steep slope. Veloz Maggiolo counted 124 mounds using aerial photos and limited surface surveys [58] (pp. 311-313), [59]. The current photogrammetric GIS study challenges these results and suggests that the previous interpretations 
were rather inaccurate. Since the area has not been impacted by new developments in recent years, the actual topography map is very well comparable to Veloz Maggiolo's drawn plan from the 1970s but shows a very distinct picture. With the photogrammetric approach, only 42 mounds of different sizes and shapes were counted, bordering 78, mostly circular, flat areas. Large parts of the area however are covered by shrub, and the flights were done in the rainy season, with high grass affecting the count. The most prominent outcomes, however, are several long, possibly connected earthworks that delimit a flat surface of $150 \mathrm{~m}$ in length in the central area. The function of this arrangement should be the focus of investigation in future excavations.

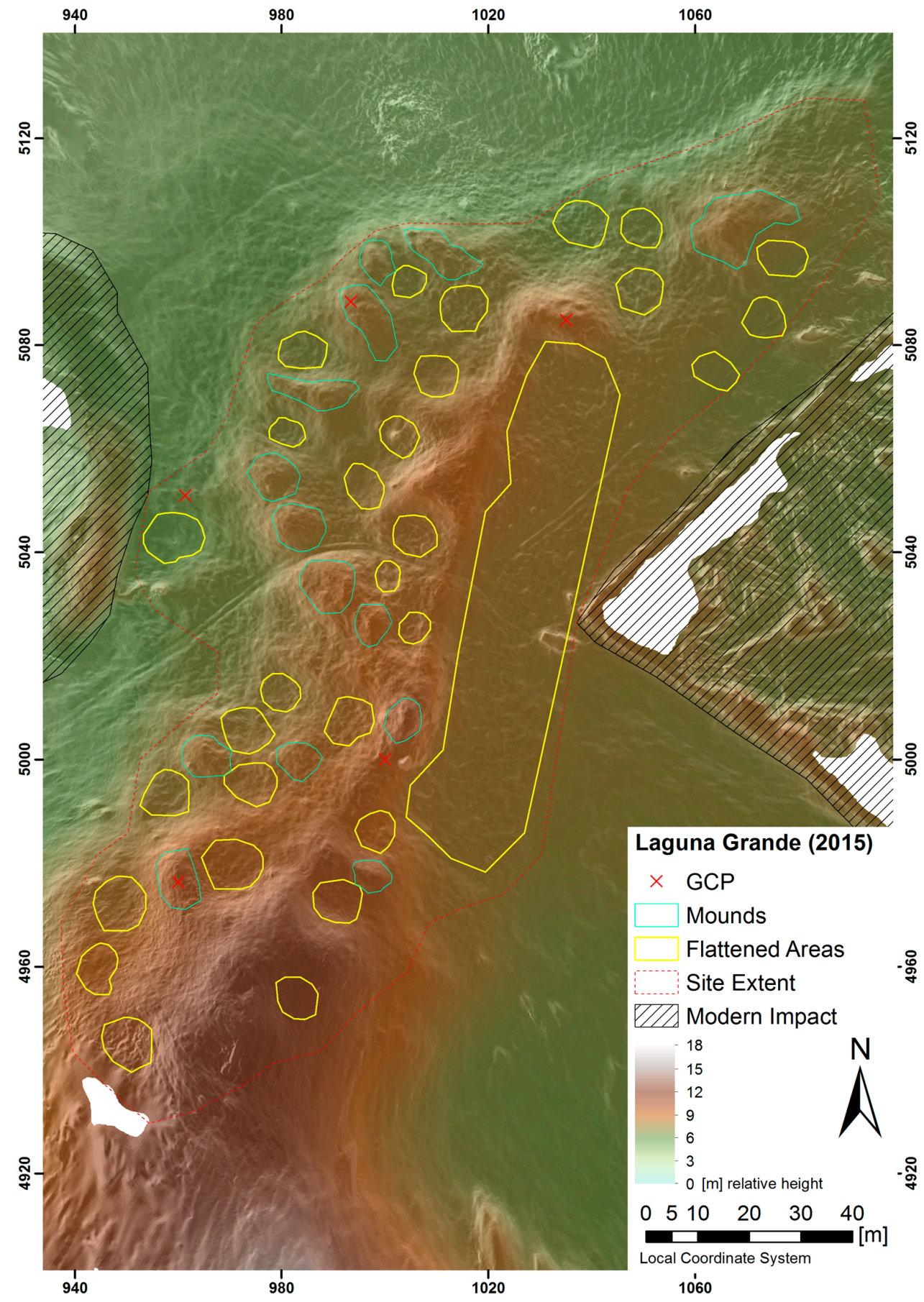

Figure 7. DEM overlaying a hillshade model, and interpretation of mounds and flattened areas of the settlement site of Laguna Grande. 


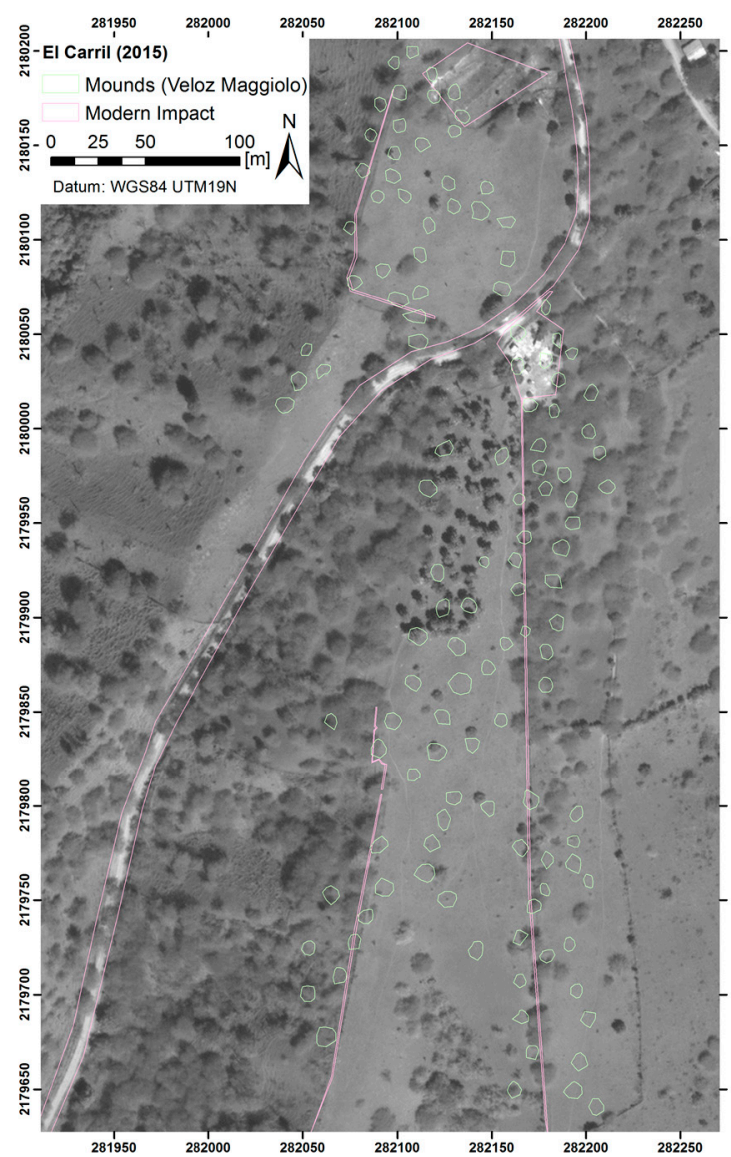

(a)

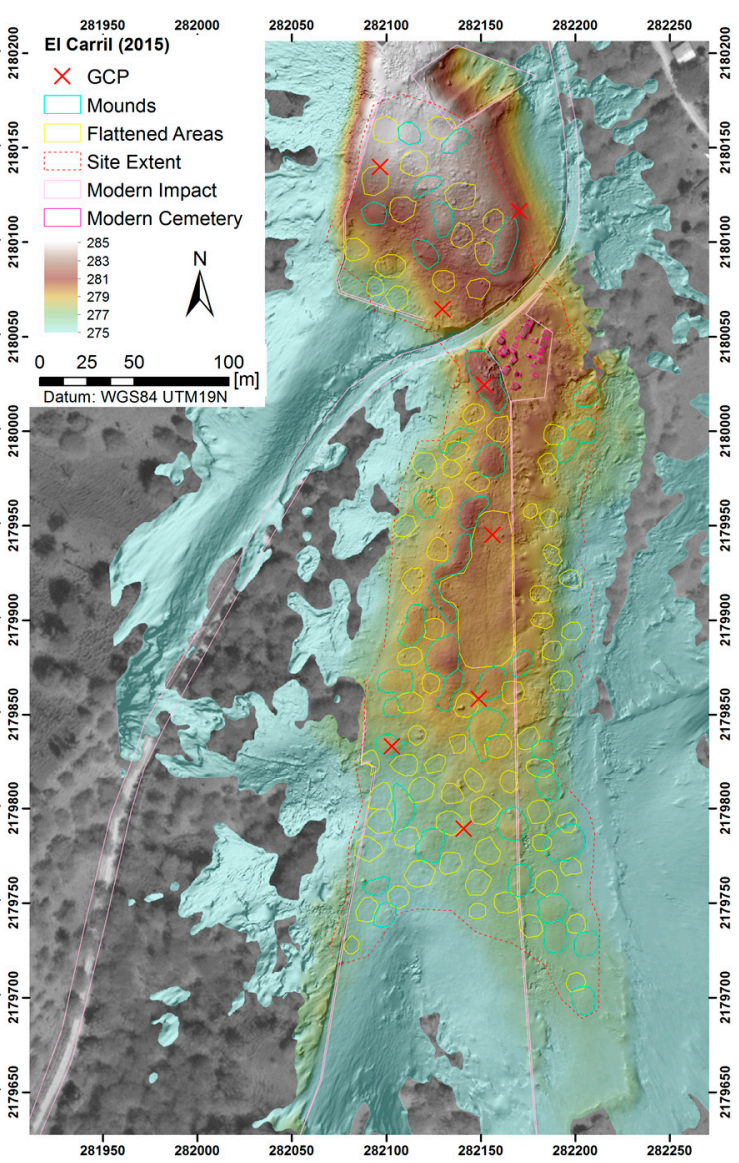

(b)

Figure 8. The mounds of El Carril (a) as envisioned by Veloz Magiollo [49]; (b) interpretation from the DEM of mounds and flattened areas. (Background: Worldview-2 Panchromatic_12MAR0215) Source: Digital Globe Foundation).

In the Greater Antilles, indigenous plazas have been characterized by large geometric spaces that had a ceremonial function, and often adjacent to areas with a residential purpose (s. a. El Atajadizo: [26] (p. 71); [60]). The extensive leveled surfaces identified in the survey are unlike the well-known indigenous ceremonial plazas in the eastern and southeastern part of the island or in Puerto Rico, demarked by vertical stones featuring petroglyphs. However, in the centre and northwest of Hispaniola, the currently known plazas, Chacuey and La Cacique, have been described as either forming an elevated ground, or a linear or oval geometry $[58,60]$, therefore not unlike the sites investigated. The plaza of Chacuey, in the northwest of the Dominican Republic, and close to the Haitian border, is a raised artificial mound (Figure 9) that was connected to the nearby river by a linear earthwork, which is now intersected by a modern road. Quite severely differentiating from the mid-twentieth century plan [61] the oval shaped mound is highlighted in the 3D model, while the purpose of the piles of small boulders in the surrounding landscape is undetermined. 


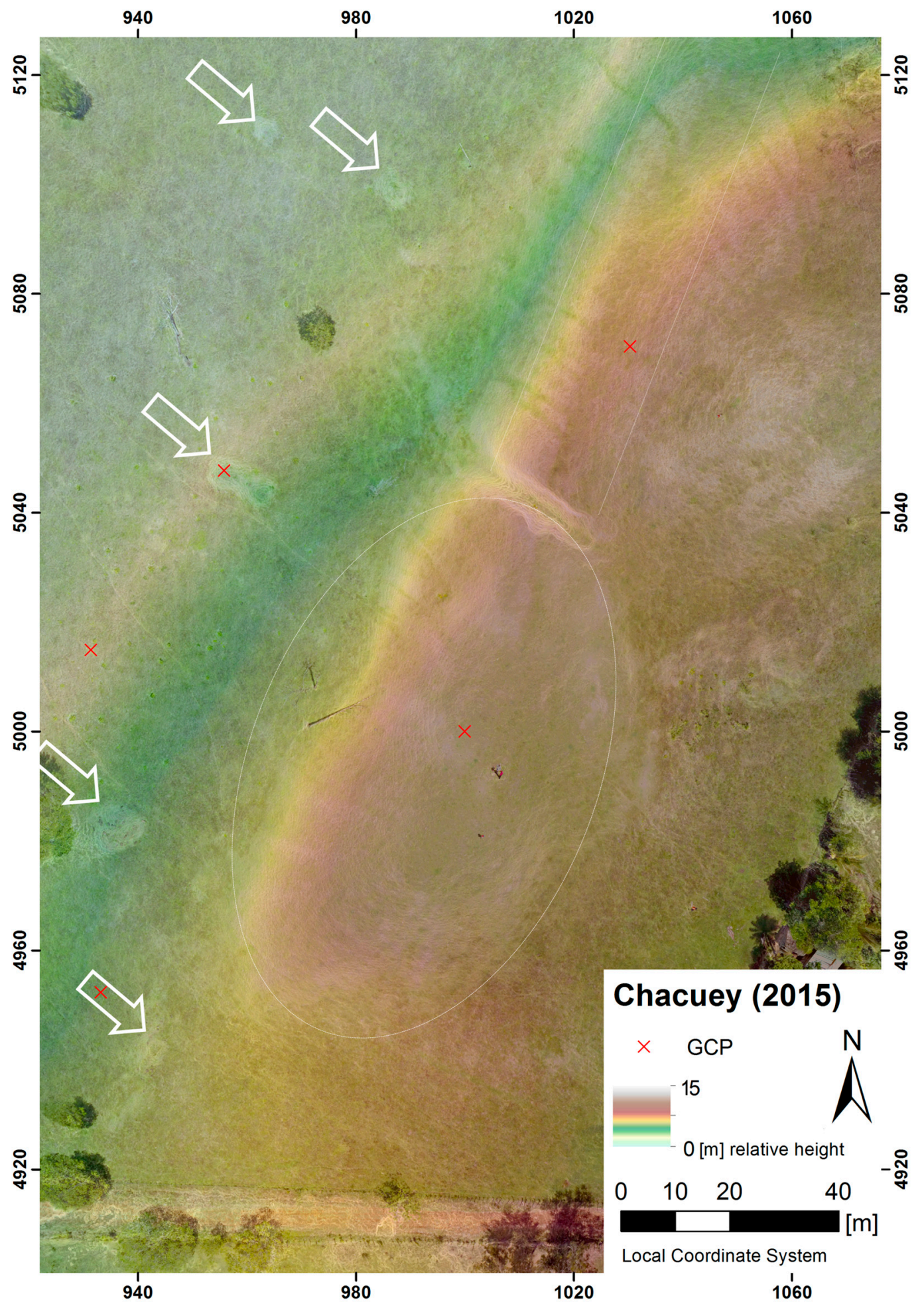

Figure 9. Orthophoto and DEM overlaying GIS slope calculations of the oval shaped mound of the ball court site of Chacuey. White arrows mark rock piles possibly associated with the former function of the site.

\section{Conclusions}

The combination of traditional archaeological and advanced technical methods to map settlement patterns in the Caribbean has proven very successful. In combination with excavations, the applicability 
of drones to create photogrammetric models provides a more comprehensive vision of the use of space by the Amerindians. Until now, traditional research emphasis had been on the mounds. However, the photogrammetric survey has served to go beyond recording only positive topography, now also including the negative imprints with emphasis on the flattened areas. The digitally enhanced visual survey of the presented eight different locations, reveals a clear organization of living space at the settlement sites. The diameter of these leveled surfaces, partly dug into the side of the hill and often circular in shape, ranges from about 7 to $15 \mathrm{~m}$. In recent excavations of circular arranged post holes, it was shown that these flattened areas served as a base for house construction; with raised earthen mounds of varying size, length and shape adjacent to them. The method highlights therefore the importance of the often ignored 'space within' in these settlements, and necessity to investigate them by novel means, such as drone photogrammetry, providing new, comprehensive information on their organization.

This only recently discovered phenomenon, the combination of mounds with flattened areas, has only been found within the 'Taíno'-sphere of interaction in the Caribbean [60-63], but not from the lesser Antilles or Central America, making it a unique type of settlement. In northern Hispaniola, the observed landscape transformation, however, can be traced in various locations over the complete region that created a particular settlement type. The opportunity to quantify the human impact and living space and estimate the size of the settlements offers a new classification into large, medium or small settlements through primary distinction of its features, according to the extent of earthen remodeling and the number of features detected. An interesting additional rationale from the diagrams, which places the size of the settlement by number of mounds/flattened areas against the size of these features (Figure 10) is that mounds and flattened areas are considerably larger in settlements of great dimensions, such as Percio Cruz and particularly El Carril.

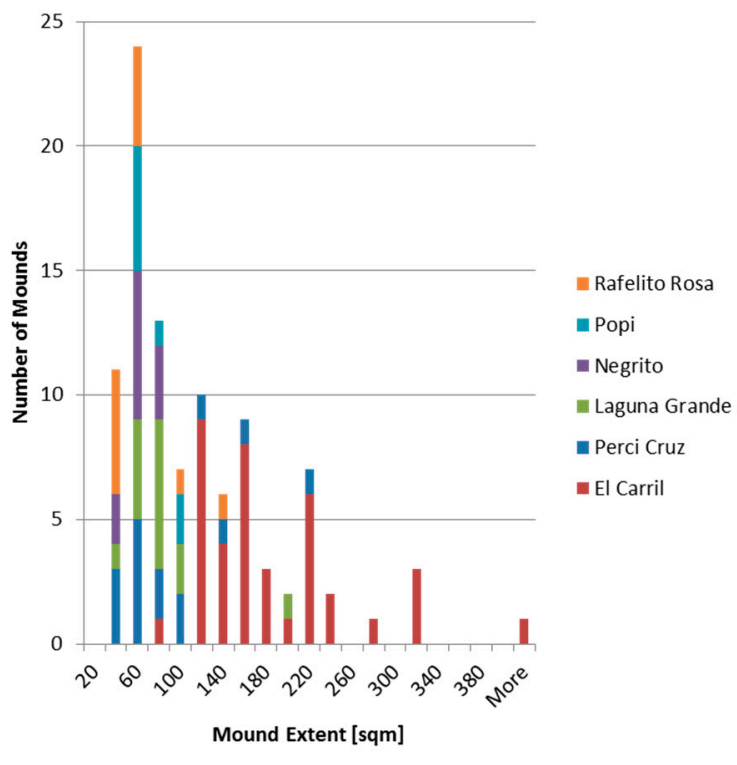

(a)

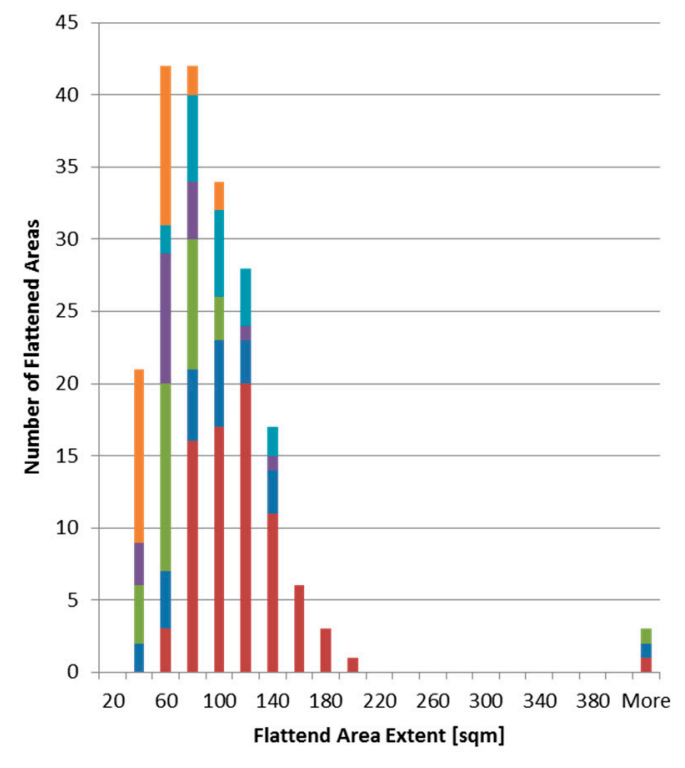

(b)

Figure 10. Comparison of the number of the (a) mounds and (b) flattened areas of the Indigenous settlement sites vs. their size, indicate mounds and flattened areas are of greater dimension in larger settlements.

As mapped in earlier studies, depending on the season, all settlement sites would have had access to nearby water sources [10]. The natural topography possibly impacted not only the population size of the settlements. Limited by natural boundaries such as steep slopes or ridges, the smaller sites on the upper slopes of the hills may have been strategically placed to manage the region from different 
locations. By establishing areas of different activities, as well as strategies of interaction, to connect multiple locations and control the space within. Open sites, unbounded by natural barriers and situated in places that provided a relatively broad and flat surface, such as El Carril or Laguna Grande, still show heavy transformations of the landscape. El Carril, with its strategic location guarding a narrow pass through the cordillera, is extraordinary in size; the number of detected earthen features exceeds any other investigated settlement by far, therefore clearly indicating that it must have had an exceptional role. Here, like at the other larger settlements, evidence of a centralized, enclosed space indicates a communal purpose. It would be reasonable to make it the focus of archaeological research of the Nexus1492 Project in upcoming years. In general, the study has shown the great potential of applying drones in landscape archaeology to reveal small, human made transformations that are not quantifiable using traditional techniques. With increasing flight time and pay load (to add different sensors), maneuverability, and the possibility to plan and schedule the flight path for efficient coverage, drones offer an economic and reliable solution to analyze archaeology and heritage sites of much larger dimensions, becoming an actual rival to LiDAR surveys.

Acknowledgments: The research leading to these results, as part of the Nexus1492 project, has received funding from the European Research Council under the European Union's Seventh Framework Programme (FP7/2007-2013)/ERC grant agreement No. 319209. We gratefully acknowledge the contributions of Menno Hoogland, Eduardo Herrera Malatesta, Samantha de Ruiter, Emma de Mooij for their help in the data collection. The Instituto Tecnológico de Santo Domingo provided the GPR equipment, while the Digital Globe Foundation provided high resolution Worldview-2 imagery.

Author Contributions: T. Sonnemann and J. Ulloa Hung have collected the data in the field choosing sites based on earlier surveys by Ulloa Hung. T. Sonnemann has conducted the drone and GPR surveys, performed the processing and data analysis, and made the figures. J. Ulloa Hung and C. L. Hofman have contributed with background knowledge on Caribbean archaeology and Amerindian mounds and clarifying terminology. The research was financed by the Nexus1492 project, of which C. L. Hofman is principal investigator.

Conflicts of Interest: The authors declare no conflict of interest.

\section{References}

1. Las Casas, B. Historia de Las Indias TII; Imprenta de Miguel Ginesta: Madrid, Spain, 1875.

2. Colón, F. Vida del Almirante; Fondo de Cultura Económica: Ciudad de México, Mexico, 1947.

3. Samson, A.V.M. Renewing the House. Trajectories of Social Life in the Yucayeque (Community) of El Cabo, Higuey, Dominican Republic, AD 800 to 1504; Sidestone Press: Leiden, The Netherlands, 2010.

4. Hofman, C.L.; Hoogland, M.L. Investigaciones arqueológicas en los sitios El Flaco (Loma de Guayacanes) y La Luperona (Unijica). Informe pre-liminar. Bol. Mus. Hombre Dominic. 2015, 46, 61-74.

5. Boyrie Moya, E. Cinco años de Arqueología Dominicana. In Anales de la Universidad de Santo Domingo; Universidad de Santo Domingo: Santo Domingo, Dominican Republic, 1960; pp. 33-86.

6. Veloz Maggiolo, M.; Ortega, E. Nuevos hallazgos arqueológicos en la costa norte de Santo Domingo. Bol. Mus. Hombre Dominic. 1980, 13, 11-48.

7. Veloz Maggiolo, M.; Ortega, E.; Caba, Á. Los Modos de Vida Meillacoides y sus Posibles Orígenes; Editora Taller: Santo Domingo, Dominican Republic, 1981.

8. Ortega, E.; Denis, P.; Olsen Bogaert, H. Nuevos yacimientos arqueológicos en Arroyo Caña. Bol. Mus. Hombre Dominic. 1990, 23, 29-40.

9. Moore, C.; Tremmel, N. Clark Moore's Archaeological Map of Haiti. Available online: http://www. nilstremmel.com/haiti/images/Clark_Moore_Haiti_sites.kmz (accessed on 20 September 2015).

10. Ulloa Hung, J. Arqueología. en la Línea Noroeste de La Española Paisajes, Cerámicas e Interacciones; Instituto Tecnológico de Santo Domingo: Santo Domingo, Dominican Republic, 2014.

11. Ulloa Hung, J. Informe de los Trabajos de Campo Realizados en Junio-Julio 2014; Proyecto NEXUS 1492; Inédito, Museo del Hombre Dominicano: Santo Domingo, Dominican Republic, 2014.

12. Ulloa Hung, J.; de Ruiter, S. Arqueología en la línea noroeste de la República Dominicana. Un esbozo del paisaje arqueológico y las interacciones. Caribe Arqueol. 2011, 12, 60-75. 
13. Deagan, K. Initial Encounters: Arawak Responses to European Contact at En Bas Saline Site, Haiti. In Proceedings of the First San Salvador Conference Columbus and His World, North Cansas City, MO, USA, 30 October-3 November 1987; pp. 341-359.

14. Deagan, K.; Cruxent, J.M. From contact to criollos: The archaeology of Spanish Colonization in Hispaniola. Proc. Br. Acad. 1993, 81, 67-104.

15. Ulloa Hung, J.; Herrera Malatesta, E. Investigaciones Arqueológicas en el Norte de La Española, Entre Viejos Esquemas y Nuevos Datos; Boletín del Museo del Hombre Dominicano: Santo Domingo, Dominican Republic, 2015.

16. Herrera Malatesta, E. La Construcción del Territorio en el Nuevo Mundo: Cartografía colonial y asentamientos indígenas en el norte de la Republica Dominicana. Chungara, Revista de Antropologia Chilena 2016, submitted.

17. Ortega, E.; Veloz Maggiolo, M. Excavación Arqueológica en el vasto residuario indígena de Hatillo Palma. Rev. Dominic. Arqueol. Antropol. 1972, 2, 5-27.

18. Luna Calderón, F. El cementerio de La Unión. Provincia Puerto Plata. Bol. Mus. Hombre Dominic. 1973, 2, 130-146.

19. Peña Sosa, S. Aspectos Arqueológicos de Río San Juan. Bol. Mus. Hombre Dominic. 1978, 11, 131-140.

20. Marichal, P. Poblamientos aborígenes de la zona del Montecristi Histórico. Bol. Mus. Hombre Dominic. 1994, 26, 15-32.

21. Keegan, W.F. Archaeological Investigations on Ile A Rat, Haití. In Association Internationale d'Archéologie de la Caraïbe Région Guadeloupe, Proceedings of the 18th International Congress for Caribbean Archaeology, Grenada, West Indies, 11-17 July 1999; pp. 233-239.

22. Olsen Bogaert, H.; Pagán Perdomo, D.; Munera, L.C. Estudio de Impacto Ambiental Selección de Rutas y Topografía de líneas de Transmisión y subestaciones Aspectos Arqueológicos; Archived manuscript; Museo del Hombre Dominicano: Santo Domingo, Dominican Republic, 2000.

23. De Grossi, J.; Tavarez, C.; Coppa, A. Reporte preliminar de los restos arqueozoológicos de Loma Perenal (Puerto Plata, República Dominicana, XII-XIII siglo AD). Bol. Mus. Hombre Dominic. 2008, 42, 317-323.

24. Koski-Karell, D. Prehistoric Northem Haïti Settlement in Diacronic Ecological Context. Ph.D. Thesis, Catholic University of America, Washington, DC, USA, 2002.

25. Sonnemann, T.; Herrera Malatesta, E.; Hofman, C.L. Applying UAS Photogrammetry to Analyze Spatial Patterns of Indigenous Settlement Sites in the Caribbean. In The Age of Sensing; Forte, M., Campana, S., Eds.; Springer Books: New York, NY, USA, 2016; in press.

26. Veloz Maggiolo, M.; Vargas Arenas, I.; Sanoja, M.; Luna Calderón, F. Arqueología de Yuma; Editora Taller: Santo Domingo, Dominican Republic, 1976.

27. Samson, A.V.M.; Hoogland, M.L.P. Residencia taina: Huellas de asentamiento en El Cabo. República Dominicana. Caribe Arqueol. 2007, 10, 93-102.

28. Hofman, C.L.; Hoogland, M.L.P.; Samson, A.V.M.; Oliver, J.R. Investigaciones Arqueológicas En El Cabo, Oriente de La República Dominicana: Resultados Preliminares de Las Campañas 2005 y 2006. Bol. Mus. Hombre Dominic. 2008, 42, 307-316.

29. López Belando, A. El Sitio Arqueológico Playa Grande Río San Juan, María Trinidad Sánchez Informe de las Excavaciones Arqueológicas Campaña 2011-2012; Museo del Hombre Dominicano: Santo Domingo, Dominican Republic, 2012.

30. Deagan, K. Reconsidering Taino social dynamics after Spanish conquest: Gender and class in culture contact studies. Am. Antiq. 2004, 69, 597-626. [CrossRef]

31. Veloz Maggiolo, M. La Isla de Santo Domingo Antes de Colón; Banco Central de la República Dominicana: Santo Domingo, Dominican Republic, 2003.

32. De Ruiter, S. Mapping History. An Analysis of Site Locations in the North-Western Dominican Republic. Master's Thesis, Leiden University, Leiden, The Netherlands, 2012.

33. Welch, D. Geophysical Prospection at the Ceremonial Site of Tibes, 1998-2001. In Tibes, People, Power, and Ritual at the Center of the Cosmos; Curet, L.A., Stringer, L.M., Eds.; University Alabama Press: Tuscaloosa, AL, USA, 2010; pp. 60-79.

34. Medica, D.; Mušič, B.; Samson, A. Recognition and interpretation of shallow microrelief features in limestone bedrock using the ground penetrating radar method, the case of El Cabo, Dominican Republic. Arheo 2010, 27, 15-43. (In Slovenian) 
35. Pincus, J.; Carr, R.; Whitman, D. Forthcoming. In Imaging Sub-Surface Features of the Miami Circle with GPR; University of Arizona's Archaeological Sciences of the Americas Inaugural Symposium: Tucson, AZ, USA. Available online: http://www.mnemotrix.com/geo/mcircle/m_circ.doc (accessed on 2 May 2015).

36. Opitz, R.; Ryzewski, K.; Cherry, J.; Moloney, B. Using Airborne LiDAR Survey to explore Historic-era archaeological landscapes of Montserrat in the Eastern Caribbean. J. Field Archaeol. 2015, 40, 523-541. [CrossRef]

37. Aqdus, S.A.; Hanson, W.S.; Drummond, J. The potential of hyperspectral and multi-spectral imagery to enhance archaeological cropmark detection: A comparative study. J. Arch. Sci. 2012, 39, 1915-1924. [CrossRef]

38. Tapete, D.; Cigna, F.; Masini, L.; Lasaponara, R. Prospection and monitoring of the archaeological heritage of Nasca, Peru with ENVISAT SAR. Archaeol. Prospect. 2013, 20, 133-147. [CrossRef]

39. Sonnemann, T. Spatial configurations of water management at an early Angkorian capital—Combining GPR and TerraSAR-X data to complement an archaeol map. Arch. Prospect. 2015, 22, 105-115. [CrossRef]

40. Nex, F.; Remondino, F. UAV: Platforms, regulations, data acquisition and processing. In 3D Re-Cording and Modelling in Archaeology and Cultural Heritage; Remondino, F., Campana, S., Eds.; BAR: Oxford, UK, 2014; pp. 73-88.

41. Remondino, F. Photogrammetry-Basic theory. In 3D Recording and Modelling in Archaeology and Cultural Heritage; Remondino, F., Campana, S., Eds.; BAR: Oxford, UK, 2014; pp. 63-72.

42. Eisenbeiss, H.; Lambers, K.; Sauerbier, M.; Li, Z. Photogrammetric documentation of an archaeological site (Palpa, Peru) using an autonomous model helicopter. In Proceedings of the CIPA 2005 XX International Symposium, Torino, Italy, 26 September-1 October 2005.

43. Sonnemann, T.; Sauerbier, M.; Remondino, F.; Schlotter, G. Reality-based 3D modelling of Angkor Temples using aerial images. In Proceedings of the 2nd International Conference on Remote Sensing in Archaeology from Space to Place, Oxford, UK, 4-7 December 2006; pp. 573-579.

44. Eisenbeiss, H.; Sauerbier, M. Investigation of UAV systems and flight modes for photogrammetric applications. Photogramm. Rec. 2011, 26, 400-421. [CrossRef]

45. Lo Brutto, M.; Borrusco, A.; D'Argenio, A. UAV systems for photogrammetric data acquisition of archaeological sites. Int. J. Herit. Digit. Era 2012, 1, 7-14. [CrossRef]

46. De Reu, J.; Plets, G.; Verhoeven, G.; De Smedt, P.; Bats, M.; Cherretté, B.; De Maeyer, W.; Deconynck, J.; Herremans, D.; Laloo, P.; et al. Towards a three-dimensional cost-effective registration of the archaeological heritage. J. Archaeol. Sci. 2012, 40, 1108-1121. [CrossRef]

47. Gutiérrez, G.; Erny, G.; Friedman, A.; Godsey, M.; Gradoz, M. Archaeological topography with small unmanned aerial vehicles. SAA Archaeol. Rec. 2016, 16, 10-13.

48. Harrison-Buck, E.; Willis, M.; Walker, C. Using drones in a threatened archaeological landscape-Rapid survey salvage and mapping of the Maya site of Saturday Creek, Belize. SAA Archaeol. Rec. 2016, 16, 30-35.

49. Sauerbier, M.; Eisenbeiss, H. UAVs for the Documentation of Archaeological Excavations. Int. Arch. Photogram. Remote Sens. Spat. Inf. Sci. 2010, 38, 526-531.

50. Soto Zamora, M.A.; Pacheco Martinez, J.; Sonnemann, T. Application of Digital Photogrammetric Survey Techniques to the Conservation of Heritage Monuments in the Camino Real de Tierra Adentro; Talk at Aid Monuments: Perugia, Italy, 2015.

51. Zakšek, K.; Oštir, K.; Kokalj, Ž. Sky-View factor as a relief visualization technique. Remote Sens. 2011, 3, 398-415. [CrossRef]

52. Guerrero, J.; Veloz Maggiolo, M. Los Inicios de la Colonización en América; Universidad Central del Este: San Pedro de Macorís, Dominican Republic, 1988.

53. Ortega, E. La Isabela y la Arqueología en la ruta de Cristóbal Colón; Universidad Central del Este: San Pedro de Macorís, Dominican Republic, 1988.

54. Deagan, K.; Cruxent, J.M. Columbus's Outpost among the Tainos Spain and America at La Isabela; Yale University Press: New Haven, CT, USA, 2002; pp. 1493-1498.

55. Ulloa Hung, J.; Sonnemann, T. Exploraciones en la ruta de Colón de 1494. Una nueva aproximación arqueológica a la Fortaleza de Santo Tomás de Jánico y su entorno. Ciencia y Sociedad 2016. Submitted.

56. Sonnemann, T. Opportunities for Remote Sensing in Caribbean Archaeology. In Proceedings of the 26th International Association for Caribbean Archaeology Congress, Maho Reef, Sint Maarten, 19-25 July 2015.

57. Casas de las Fray, B. Apologética. Historia Sumaria de las Indias; Alianza: Madrid, Spain, 1992. 
58. Veloz Maggiolo, M. Arqueología. Prehistórica de Santo Domingo; McGraw Hill: Singapore, 1972.

59. Veloz Maggiolo, M. Notas sobre los modelos de ocupación prehistórica en la isla de Santo Domingo. Bol. Mus. Hombre Dominic. 1979, 12, 49-57.

60. Alegría, R. Ball Courts and Ceremonial Plazas in the West Indies (Yale University Publications in Anthropology); Yale University Press: New Haven, CT, USA, 1983; Volume 79.

61. Boyrie Moya, E. Monumento Megalítico y Petroglifos de Chacuey, República Dominicana; Editora del Caribe C. x A.: Ciudad Trujillo, Dominican Republic, 1955.

62. Rainey, F.G. Excavations in the Ft. Liberté Region; Yale University Press: New Haven, CO, USA, 1941.

63. Guarch, J.M. El Taino de Cuba: Ensayo de Reconstrucción Etnohistórica; Instituto de Ciencias Sociales, Academica de Ciencias de Cuba: Havana, Cuba, 1978.

(C) 2016 by the authors; licensee MDPI, Basel, Switzerland. This article is an open access article distributed under the terms and conditions of the Creative Commons Attribution (CC-BY) license (http://creativecommons.org/licenses/by/4.0/). 